\title{
EMERGENCY REPORTING PROCEDURE IN A MULTI-NATIONAL ENVIRONMENT
}

This article is aimed on reporting procedure in emergency situation used in multi-national environment. It is based on real procedures, documents and instructions, which are usually used in all kinds of emergency assets, especially during the activities of multi-national joint forces. The first impulse for creating this procedure started in armed task forces and due to the great effect fluently increased to the civilian sector. The article is a basic instruction how to simply ensure information flowchart among all the elements and secure quick reaction on developing crisis situation.

\section{Introduction}

Crisis management is a phenomenon of the present time. Nowadays, the increasing numbers of predicaments are solved in a multi-national environment. In the case of emergency quick reaction and efficiency are the fundamental characteristics in order to ensure a proper coordination of the rescue assets immediately. A precise, punctual and timely management of assets that effect through a simple chain of command, can only achieve this. Different operation procedures, capabilities and language barriers of the involved international assets brought about the need to create a common system of reporting procedure. The main purpose of this article is to create an overall summary of the multi-national standard operation procedures (SOP), information flowcharts (IF) and reporting procedures (RP) in order to explain its application in the real situation.

All these mentioned segments are the necessary parts of a decision making process (DMP) and the most important inputs in the process of gathering information in order to get enough relevant information for the general solution of the situation.

We can divide this problem into three parts:

- standard operation procedures (SOP)

- information flowcharts (IF)

- reporting procedures (RP)

\section{Standard operation procedures}

Aim of the SOPs is to clarify the procedures used by the crisis management. The main intent of each SOP is to support the members and managers of the crisis staff and incident comman- der in DMP and help them to make particular decisions aimed to reach the final goal.

The core of each SOP is a clear and simple direction, how to manage the situation in order to ensure a safe and secure environment in accordance with the official protocols and documents. SOP has to be clear and simple, but on the other hand, rich on the value.

The most important SOP for our work is the "Alert of Immediate Rescue Team (IRT) and Communication Procedures in Emergency Situation" used in the multi-national military IRT assets.

\section{Information flowchart}

The main intent of IF is to ensure the flow of information and reports to all the participants, especially between the IRT on the spot and the operation room (OPS room).

IRT assets have to react immediately and with a sufficient information flow during the incident. OPS room is responsible for the accurate and timely reporting of all information related to the incident to IRT. Each incident must be assessed individually and taken actions must be based on the received accurate information and any situational analysis from the incident site. IRT Asset Status Reports and Situational Picture are sent to the OPS room verbally through the assigned CIS (communication and information systems) systems minimum every 30 minutes.

The most widely used CIS system is the radio communication. There are several rules in the transmission in order to get the fluent flow of the information. The most important are:

\footnotetext{
* Frantisek Salenka, Dusana Salenka, Marian Furi

Army of the Slovak Republic, E-mail: dusana.salenka@mil.sk
} 
- Send the brief but precise message.

- Break the message into sensible passages with pauses between.

- Make sure no-one else is transmitting at the same time.

- By transmitting maintain the high standard of articulation, normal rhythm and moderate volume. Do not shout.

- Avoid excessive calling and unofficial voice procedures.

- Hold the microphone close to your mouth.

Phonetics

- The International Phonetic Alphabet [1] listed below shall be used.

- Numerals shall be transmitted digit by digit except round figures as hundreds and thousands.

International phonetic alphabet [1]

Table 1

\begin{tabular}{|c|c|c|c|c|c|}
\hline Letter & $\begin{array}{l}\text { Phonetic } \\
\text { Alphabet }\end{array}$ & Letter & $\begin{array}{l}\text { Phonetic } \\
\text { Alphabet }\end{array}$ & Numeral & Spoken as \\
\hline A & ALFA & $\mathrm{N}$ & NOVEMBER & 0 & ZERO \\
\hline B & BRAVO & $\mathrm{O}$ & OSCAR & 1 & WUN \\
\hline $\mathrm{C}$ & CHARLIE & $P$ & PAPA & 2 & TOO \\
\hline D & DELTA & Q & QUEBEC & 3 & THREE \\
\hline $\mathrm{E}$ & ECHO & $\mathrm{R}$ & ROMEO & 4 & FO-WER \\
\hline $\mathrm{F}$ & FOXTROT & $S$ & SIERRA & 5 & FI-YIV \\
\hline G & GOLF & $\mathrm{T}$ & TANGO & 6 & SIX \\
\hline $\mathrm{H}$ & HOTEL & $\mathrm{U}$ & UNIFORM & 7 & SEVEN \\
\hline I & INDIA & V & VICTOR & 8 & ATE \\
\hline $\mathrm{J}$ & JULIET & W & WHISKEY & 9 & NINER \\
\hline K & KILO & $\mathrm{X}$ & XRAY & \multirow{3}{*}{\multicolumn{2}{|c|}{\begin{tabular}{|l|} 
Examples: \\
12 WUN TOO \\
44 FO-WER FO-WER \\
90 NINER ZERO \\
136 WUN THREE SIX
\end{tabular}}} \\
\hline L & LIMA & Y & YANKEE & & \\
\hline M & MIKE & Z & ZULU & & \\
\hline
\end{tabular}

Procedure Words (PROWORDS) [1]

- A pro-word is a word or phrase which has been given a special meaning in order to speed up the handling of messages.

- The only authorised pro-words are listed below:

PROWORDS [1]

Table 2

\begin{tabular}{|l|l|}
\hline PROWORD & Explanation \\
\hline ALL AFTER & $\begin{array}{l}\text { The portion of the message to which I have reference } \\
\text { is all that which follows }\end{array}$ \\
\hline ALL BEFORE & $\begin{array}{l}\text { The portion of the message to which I have reference } \\
\text { is all that which precedes }\end{array}$ \\
\hline BREAK & $\begin{array}{l}\text { I hereby indicate the separation of the text from } \\
\text { other portions of the message. }\end{array}$ \\
\hline CORRECT & $\begin{array}{l}\text { You are correct, or what you have transmitted is } \\
\text { correct. }\end{array}$ \\
\hline
\end{tabular}

\begin{tabular}{|l|l|}
\hline CORRECTION & An error has been made in this transmission.
\end{tabular}

Transmission will continue with the last word correctly transmitted.

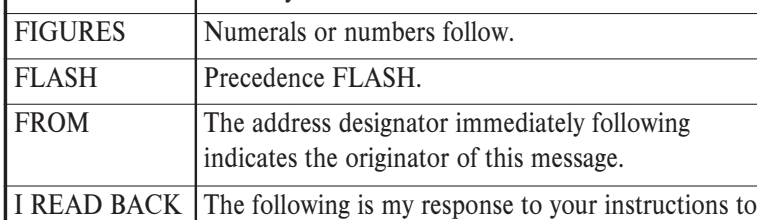
read back.

\begin{tabular}{l|l}
\hline I SAY AGAIN & I am repeating transmission or portion indicated.
\end{tabular}

\begin{tabular}{l|l}
\hline I SPELL & I shall spell the next word phonetically.
\end{tabular}

\begin{tabular}{|l|l}
\hline I VERIFY & That which follows has been verified at your request \\
\hline
\end{tabular} and is repeated. To be used only as a reply to VERIFY.

\begin{tabular}{l|l}
\hline MESSAGE & A message which requires recording is about to
\end{tabular} follow. Transmitted immediately after the call. (This PROWORD is not used on nets primarily employed for conveying messages. It is intended for use when messages are passed on tactical or reporting nets.)

\begin{tabular}{|l|l}
\hline OUT & This is the end of my transmission to you and no
\end{tabular} answer is required or expected.

\begin{tabular}{|l|l}
\hline OVER & This is the end of my transmission to you and
\end{tabular} a response is necessary. Go ahead, transmit.

\begin{tabular}{l|l}
\hline READ BACK & Repeat this entire transmission back to me exactly as
\end{tabular} received.

\begin{tabular}{l|l}
\hline RELAY (TO) & Transmit this message to all addressees (or
\end{tabular} addressees immediately following this PROWORD). The address component is mandatory when this PROWORD is used.

\begin{tabular}{|l|l}
\hline ROGER & I have received your last transmission satisfactorily.
\end{tabular}

\begin{tabular}{|l|l}
\hline SAY AGAIN & Repeat all of your last transmission. Followed by
\end{tabular} identification data means "Repeat (portion indicated)".

SILENCE $\quad$ Cease transmission on this net immediately. Silence

(Repeated three will be maintained until lifted. (When an authenticaor more times) tion system is in force, the transmission imposing silence is to be authenticated).

SILENCE $\quad$ Silence is lifted. (When an authentication system is

LIFTED in force, the transmission lifting silence is to be authenticated).

\begin{tabular}{l|l}
\hline SPEAK & Your transmission is at too fast a speed. Reduce
\end{tabular}

SLOWER speed of transmission.

\begin{tabular}{|l|l}
\hline THIS IS & This transmission is from the station whose designa-
\end{tabular} tor immediately follows.

\begin{tabular}{|l|l|}
\hline TIME & $\begin{array}{l}\text { That which immediately follows is the time or date } \\
\text { time-time group of the message. }\end{array}$ \\
\hline TO & $\begin{array}{l}\text { The addressees immediately following are addressed } \\
\text { for action. }\end{array}$ \\
\hline $\begin{array}{l}\text { UNKNOWN } \\
\text { STATION }\end{array}$ & $\begin{array}{l}\text { The identity of the station with whom I am } \\
\text { attempting to establish communication is unknown. }\end{array}$ \\
\hline WAIT & I must pause for a few seconds. \\
\hline WAIT - OUT & I must pause longer than a few seconds. \\
\hline WILCO & $\begin{array}{l}\text { I have received your signal, understand it, and will } \\
\text { comply. To be used only by the addressee. }\end{array}$ \\
\hline
\end{tabular}




\begin{tabular}{|l|l|}
\hline WORD AFTER & $\begin{array}{l}\text { The word of the message to which I have reference is } \\
\text { that which follows }\end{array}$ \\
\hline $\begin{array}{l}\text { WORD } \\
\text { BEFORE }\end{array}$ & $\begin{array}{l}\text { The word of the message to which I have reference is } \\
\text { that precedes }\end{array}$ \\
\hline $\begin{array}{l}\text { WORDS } \\
\text { TWICE }\end{array}$ & $\begin{array}{l}\text { Communication is difficult. Transmit (transmitting) } \\
\text { each phrase (or each code group) twice. This } \\
\text { PROWORD may be used as an order, request, or as } \\
\text { information. }\end{array}$ \\
\hline WRONG & $\begin{array}{l}\text { Your last transmission was incorrect. The correct } \\
\text { version is }\end{array}$ \\
\hline
\end{tabular}

\section{Emergency reporting procedure}

In the multi-national reporting procedures reporting forms are usually used. These ones make the information flowchart about the situation easier. Each form must be very strict and comprehensible.

Advantages of the reporting form:

- time saving

- well arranged information

- elimination of the missing information

- easy use for everyone

- low level of the needed language skills

"Request for IRT support" is the most important reporting form in the emergency reporting procedure. Forms and examples (in accordance with SOP: "Alert of Immediate Rescue Team (IRT) and Communication Procedures in Emergency Situation”) of these requests are described below.

When reporting any accident/incident or emergency situation comply with the Medical Emergency Aide Memoire known as METHANE Report [2]:

Fig. 1 METHANE Report [2]

\begin{tabular}{|l|l|}
\hline \multicolumn{2}{|c|}{ M-E-T-H-A-N-E } \\
\hline DTG & $\begin{array}{l}\text { Date, Time, Group * } \\
\text { 29 0935B SEP 2009 }\end{array}$ \\
\hline M & $\begin{array}{l}\text { My call sign (name, team) } \\
\text { ECHO 21 }\end{array}$ \\
\hline E & $\begin{array}{l}\text { Exact location (GRID - or describe location) } \\
\text { GRID: EN 12300 35400 }\end{array}$ \\
\hline T & $\begin{array}{l}\text { Type of incident (e. g. RTA) } \\
\text { RTA (route traffic accident) of bus and vehicle. }\end{array}$ \\
\hline H & $\begin{array}{l}\text { Hazard at the scene (e. g. Traffic, fire) } \\
\text { Possible burning vehicle, unknown liquid and hard traffic }\end{array}$ \\
\hline
\end{tabular}

\begin{tabular}{|l|l|}
\hline A & $\begin{array}{l}\text { Access (route in, GRID of RV *, HLS * } \\
\text { Main route in vicinity of village XY. South route to main junction. } \\
\text { Possible HLS at GRID: EN 009 135 with no hazards, marks } \\
\text { with blue smoke. }\end{array}$ \\
\hline $\mathrm{N}$ & $\begin{array}{l}\text { Number and type of casualties } \\
\text { Approximately 9 casualties. Number of wounds. Impacts, exter- } \\
\text { nal bleedings, possible wound of backbone, burns and trauma } \\
\text { injuries. } \\
(2 \text { - urgent, 7 - priority precedence) } \\
(2 \text { - litter, 7 - ambulant) }\end{array}$ \\
\hline E & $\begin{array}{l}\text { Emergency assets present and needed (e. g. IRT, firemen) } \\
\text { Medical teams and FIREMEN. Medical assets and extraction } \\
\text { equipment required. Urgently. } \\
\text { Police to secure the area and provide bypass. } \\
\text { No assets currently present. BPT (be prepared to) HELIVAC. }\end{array}$ \\
\hline
\end{tabular}

In Mass Casualty Situation (MASCAL) incident commander requests helicopter medical evacuation (Heli MEDEVAC) if required, for evacuation of injured persons. Make the request usually using 9-Line MEDEVAC REQUEST [3], in this type of situation.

\section{Required Information [5]}

a. Header Message

(1) Date-Time Group (DTG)

(2) Identifier/Unit Name/Name

b. 9-Lines Test as follows:

(1) Pickup Zone (PZ) Grid Reference Provide the 6-figure grid reference and any other pertinent landmarks, town location, etc, that will help identify the location of the casualties.

(2) Radio Call Sign (C/S) and Frequency (Freq)/Phone number Fill in the call sign of IRT (on-site commander, incident commander, reporting person who are still in touch) and primary and alternate frequency or phone number.

(3)Number of Patients and Precedence (Patients by precedence)

Provide the number of casualties awaiting the evacuation by category.

\section{A/P1 Priority 1 / URGENT}

Emergency patients who require speedy evacuation that is necessary to save life, to prevent complications or to avoid serious permanent disability.

B/P2 Priority 2 / PRIORITY

Patients who require specialised treatment not available locally and who are liable to deteriorate unless evacuated with the least possible delay.

C/P3 Priority 3 / ROUTINE

Patients who require immediate treatment that is available locally but whose prognosis would benefit from air evacuation on routine scheduled flights.

* DTG: 29 0930Z SEP 2009 means 29 SEP 2009, 09:30, Z: local time

* GRID of RV - exact location of rendezvous (meeting) point marked with 6-figure grid reference

* HLS - Helicopter landing site 
Fig. 2 9-line MEDEVAC REQUEST [3]

\begin{tabular}{|c|c|c|c|c|}
\hline \multicolumn{3}{|c|}{ MEDEVAC “ 9-Line” REQUEST } & \multicolumn{2}{|r|}{ UNIT (NAME) } \\
\hline 1 & \multicolumn{2}{|c|}{ LOCATION (GRID OF PICKUP ZONE) } & \\
\hline 2 & \multicolumn{2}{|c|}{ CALLSIGN \& FREQ (PHONE NUMBER) } & \multicolumn{2}{|l|}{ (2) } \\
\hline 3 & \multicolumn{2}{|c|}{ NUMBER OF PATIENTS/PRECEDENCE } & \multicolumn{2}{|l|}{ (3) $\mathrm{A} \ldots \ldots \ldots \ldots . . . \mathrm{B} \quad \ldots \ldots \ldots \ldots . . . \mathrm{C}$} \\
\hline & \multicolumn{2}{|c|}{$\begin{array}{l}\text { A - URGENT; to be at hospital facility (R2 or R3) } \\
\text { within } 90 \text { minutes of first notification (P1) }\end{array}$} & \multicolumn{2}{|c|}{$\begin{array}{l}\text { B - PRIORITY; to be at hospital facility ( } 2 \text { or R3) within } 4 \text { hours of } \\
\text { notification by "9-line" (P2) }\end{array}$} \\
\hline & \multicolumn{2}{|c|}{$\begin{array}{l}\text { C - ROUTINE; to be at hospital facility R2/R3 } \\
\text { within } 24 \text { hours of notification by "9-line” (P3) }\end{array}$} & & \\
\hline \multirow[t]{2}{*}{4} & \multicolumn{2}{|c|}{ SPECIAL EQUIPT REQ’D } & \multicolumn{2}{|l|}{$(4)$} \\
\hline & A - NONE & B - HOIST (Winch) & C - EXTRICATION & \\
\hline \multirow[t]{2}{*}{5} & \multicolumn{2}{|c|}{ NUMBER TO BE CARRIED LYING/SITTING } & \multicolumn{2}{|l|}{ 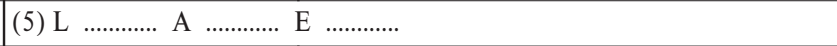 } \\
\hline & L - LITTER (Stretcher) & \multicolumn{2}{|c|}{ A - AMBULATORY (WALKING) } & E - ESCORTS (e.g. for child patient) \\
\hline \multirow[t]{3}{*}{6} & \multicolumn{2}{|c|}{ SECURITY AT PICKUP ZONE (PZ) } & \multicolumn{2}{|l|}{ (6) } \\
\hline & \multicolumn{2}{|l|}{$\mathrm{N}$ - No threat } & \multicolumn{2}{|l|}{ E - Explosion } \\
\hline & \multicolumn{2}{|l|}{ L - Unknown liquid } & \multicolumn{2}{|c|}{$\mathrm{X}$ - Nuclear, biologocal and chemical dangerous } \\
\hline \multirow[t]{2}{*}{7} & \multicolumn{2}{|c|}{ PICKUP ZONE (PZ) MARKING METHOD } & \multicolumn{2}{|l|}{ (7) } \\
\hline & A - PANELS & B - PYRO & C - SMOKE & E - OTHER (explain) \\
\hline \multirow[t]{3}{*}{8} & \multicolumn{2}{|c|}{ NUMBER OF PATIENTS BY STATUS } & \multicolumn{2}{|l|}{ (8) A $\ldots \ldots \ldots \ldots .$. B $\ldots \ldots \ldots \ldots .$. C $\ldots \ldots \ldots \ldots$} \\
\hline & \multicolumn{2}{|l|}{ A - IRT MEMBER } & \multicolumn{2}{|l|}{ B - CIVILIAN (ADULT) } \\
\hline & \multicolumn{2}{|l|}{ C - CHILD } & & \\
\hline 9 & $\begin{array}{l}\text { PICKUP ZONE (PZ) TI } \\
\text { (describe terrain, obstacl }\end{array}$ & $\begin{array}{l}\text { RRAIN/OBSTACLES } \\
\text { and weather) }\end{array}$ & (9) & \\
\hline & DO NOT DELA & LAUNCH OF MEDEVAC & - SUPPLY FURTHER INFORMATION 0 & ILABLE: \\
\hline M & $\begin{array}{l}\text { MECHANISM OF INJU } \\
\text { (and at what time if knov }\end{array}$ & & (Time: .....................) & \\
\hline I & INJURY OR ILLNESS & JSTAINED & (I) & \\
\hline S & $\begin{array}{l}\text { SYMPTOMS AND VIT } \\
\text { A - airway B - breathing } \\
\text { scious/unconscious E - c }\end{array}$ & $\begin{array}{l}\text { SIGNS } \\
\text { ate } C \text { - pulse rate D - con- } \\
\text { her signs }\end{array}$ & $\begin{array}{r}\text { (S) } \ldots \ldots \ldots \ldots \ldots \ldots \ldots \ldots \ldots \ldots \ldots \ldots \ldots \ldots \ldots \ldots \ldots \ldots \\
\text { A } \ldots \ldots \ldots \ldots . . .\end{array}$ & \\
\hline $\mathrm{T}$ & $\begin{array}{l}\text { TREATMENT GIVEN } \\
\text { (e.g. Tourniquet and tim }\end{array}$ & applied, Morphine) & $(\mathrm{T})$ & \\
\hline
\end{tabular}

(4) Special Equipment Required

The classification defines specialized equipment to be aboard the aircraft.
A - None
B - Hoist (Winch)
C - Extrication
D - Ventilator

(5) Number of Casualties Carried Lying or Sitting (Patients by type):

The classification defines the patient's requirement for space in the aircraft.

L - Litter (stretcher) Borne Patients

A - Ambulatory (walking) Sitting Patients

E - Escorts Sitting Passengers

(6) Security at Pickup Zone

N - No threat
E - Possible explosion
L - Liquid (type or unknown)
$\mathrm{X}$ - NBC dangerous

(7) Pickup Zone Marking Method

The classification provides information how the $\mathrm{PZ}$ will be identified and marked.
A - Panels
B - Pyrotechnics
C - Smoke
D - None
E - Other (explain)

(8) Number of Patients by Status
A - IRT member
B - Civilian (Adult)
C - Child 
(9) Pickup Zone Terrain/Obstacles

The classification provides an assessment of any obstacles and the type of terrain located adjacent or at the PZ.

Terrain: - slope

- elevation

- surface

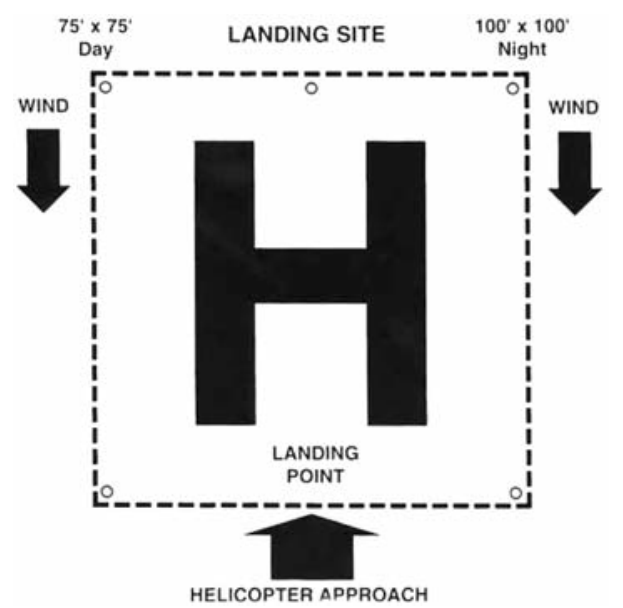

Fig. 3 Landing zone preparation [6]

\author{
Obstacle: - pylons, pillars, trees, building etc. \\ - wiring \\ - FOD (foreign object damage) \\ Weather: - visibility \\ - weather status \\ - wind (strength and direction)
}

\section{Conclusion:}

The article discuss about information flowchart and reporting procedure in multi-national environment in order to speed up the handling of information. The main effort is put on creation of reports about incidents/accidents in accordance with reporting forms, which are usually used in international emergency management. The article clarify the basic terminology and summarize gathered information gained by information research and own experiences. The main purpose was to create an overall summary of available information about reporting procedure into common document in order to explain its application in the real situation and help to emergency personnel in their daily routine work.

\section{References:}

[1] STUDY GUIDE TOPICS: Prowords [1999]. In online: <http://www.armystudyguide.com/content/ army_board_study_guide_topics/ communications/prowords-used-in-radiocommunication.shtml>

[2] EMERGENCY MEDICINE SOCIETY OF SOUTH AFRICA: Major Incident Management System, practice guideline, 3/2008.

[3] OPERATIONAL MEDICINE: Transmit a 9-Line Medical Evacuation Message [2008]. In online: <http://www.operationalmedicine.org/Videos/9LineMEDEVAC.htm>

[4] MESKO D., KATUSCAK D., FINDRA J.: Academic Guide 2 (in Slovak), Martin, Osveta 2005, ISBN: 80-8063-200-6.

[5] STANDARD OPERATION PROCEDURES: Alert of Immediate Rescue Team (IRT) and Communication Procedures in Emergency Situation, Kosovo Forces, 2009.

[6] DHART (DARTMOUTH-HITCHCOCK ADVANCED RESPONSE TEAM): Landing zone preparation [2011]. In online:

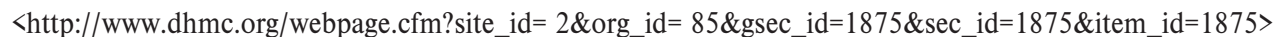

[7] ZELENY J., SLOSIARIK, J.: Risk Management (in Slovak), Zvolen, Technical Univerzity 2000, ISBN: 80-228-0892-X..

[8] HADDOW, G. D., BULLOCK, J. A.: Introduction to Emergency Management - third edition, USA, Elsevier 2008, ISBN: 978-0-75068514-6.

[9] FARAZMAND, A.: Handbook of Crises and Emergency Management, NY, Headquarters, 2001, ISBN: 0-8247-0422-3. 